\title{
CORROSION INHIBITION EFFICIENCY OF MORINGA LEAF EXTRACT (Moringa oleifera) AGAINST A36 STEEL
}

\author{
Rita Desiasni*, Mardiana, and Syamsul Hidayat \\ Metallurgical Engineering Study Program, Faculty of Environmental and Mineral Technology, Sumbawa \\ University of Technology, Sumbawa, Indonesia \\ *Email: rita.desiasni@uts.ac.id
}

Acceped: October, 27 2021. Approved: November, 03 2021. Published: November 112021

\begin{abstract}
The use of inhibitors is one of the most effective ways to control corrosion. The study aims to determine and examine more deeply the effect of variations in the concentration of organic inhibitors from Moringa leaf extract on the corrosion rate of A36 steel material in seawater media. Moringa leaf extract's effectiveness in inhibiting the corrosion rate of A36 steel material in seawater media is also determined. This research was conducted by immersing specimens with inhibitor concentrations of 0 ppm, 100 ppm, 200 ppm, 300 ppm, 400 ppm, and $500 \mathrm{ppm}$ for seven days of immersion. The corrosion rate is calculated using the weight loss method. The results showed that the corrosion rate decreased with the inhibitor concentration in the corrosion media. The inhibitor concentration of $500 \mathrm{ppm}$ Moringa leaf extract was able to inhibit the corrosion rate optimally. It is indicated by the smallest corrosion rate value of $1.07 \mathrm{mpy}$. On the other hand, the inhibitor efficiency increases with the inhibitor concentration in the corrosion media. The highest inhibitor efficiency was $78.71 \%$ at the addition of $500 \mathrm{ppm}$ inhibitor to the solution.
\end{abstract}

Keywords: Corrosion Inhibitor, Moringa Leaf, A36 Steel, Sea Water, Weight Loss.

\section{INTRODUCTION}

Currently, the use of steel as the primary material for shipbuilding is still dominant. A36 steel is one of the most common low-carbon steels used in ship hull construction applications. One of the most significant sources of damage to the hull plates is due to seawater corrosion. Corrosion decreases the quality of a metal due to its interaction with the environment and chemicals. Corrosion of metal cannot be stopped but can be controlled [1].

One method of inhibiting the corrosion process is by using a corrosion inhibitor. A corrosion inhibitor can be defined as a substance that reduces the corrosion process when added in small amounts to an environment. Many types of inorganic inhibitors are suitable for corrosion inhibition, but some are toxic to humans and the environment. These types of inhibitors need to be replaced by other nontoxic compounds capable of being biologically degraded but still have economic value and can significantly reduce the corrosion rate [2-3].

The use of natural ingredients is an innovative solution in making inhibitors. Extracts of natural ingredients have activity in inhibiting the corrosion rate because they contain heterocyclic compounds. One of the organic compounds is antioxidants. Antioxidants work by donating a pair of electrons to the surface of Fe so that it will form a complex compound that is stable and more becoming corrosion-resistant [3-4].

Moringa leaves contain antioxidant compounds that can be used to inhibit the corrosion process. The content of antioxidant power in Moringa leaves has an IC50 value of $22.1818 \mathrm{ppm}$ [5]. The active substances in Moringa leave that have the potential as antioxidants are various types of vitamins (A, C, E, K, B1, B2, B3, B6), flavonoids, alkaloids, saponins, tannins, and terpenoids.

Previous research on the use of organic inhibitors to inhibit the corrosion rate has been carried out. Various organic inhibitors used, including methanol extract of silver fern $(P$. calomelanos) reached a maximum inhibition efficiency of $57.27 \%$ in inhibiting corrosion of ASTM A36 steel [6]. Another study that used organic inhibitors used tea leaf extract (camelia sinensis) with an effectiveness of $86.3 \%$ to inhibit the corrosion rate of St.37 steel in hydrochloric acid media and $92 \%$ in sodium chloride media [7]. Bay leaf extract with effectiveness of $99.80 \%$ in controlling the corrosion rate on A36 black plate steel in $3 \% \mathrm{NaCl}$ media [8]. As well as research that Ichsan has carried out, 2008 using an organic inhibitor of Moringa leaf extract, which has an effectiveness of $69.46 \%$ in inhibiting the corrosion rate on API 5L Grade B pipeline material in seawater corrosive media [9].

Based on these, this study used Moringa leaf extract to inhibit the corrosion rate of A36 steel in seawater media. The selection of seawater media as the corrosive media is due to the high content of chloride ions $\left(\mathrm{Cl}^{-}\right)$. It will impact the speed of the corrosion rate on the main plate of the hull, whose application often interacts with the corrosive media. While the selection of Moringa leaf material as a corrosion inhibitor is due to its antioxidant content, and the material is readily available in nature. The study carried out laboratory-scale testing using A36 steel on seawater media using weight loss testing to achieve this goal. The weight loss test method is based on reducing the weight of the corroded metal. 
In addition, the test process is simple because it only calculates the initial and final weight reduction of the material.

The study aims to determine and examine more deeply the effect of variations in the concentration of organic inhibitors from Moringa leaf extract on the corrosion rate of A36 steel material in seawater media. Next, to determine the effectiveness of Moringa leaf extract to inhibit the corrosion rate of A36 steel material in seawater media.

\section{RESEARCH METHODS \\ Making Moringa Leaf Extract Inhibitor}

Fresh Moringa leaves separated from the stalks are washed with running water until clean and then drained. After that, the leaves are dried at room temperature until the Moringa leaves become dry. Dried Moringa leaves are then crushed using a blender and sieved using a filter to obtain a fine powder of Moringa leaves. A total of 367 grams of Moringa leaf powder was macerated in $3700 \mathrm{ml}$ of $96 \%$ ethanol solvent for three days. After three days of immersion, the immersion was filtered using filter paper to separate the extract from the filtrate. Then the filtrate obtained was concentrated using a rotary evaporator to get concentrated Moringa leaf extract as an inhibitor solution.

Inhibitor solutions were made in the volume of $50 \mathrm{ml}$ and various concentrations, 0 ppm, 100 ppm, 200 ppm, 300 ppm, 400 ppm, and $500 \mathrm{ppm}$, using the dilution formula. Then made a stock solution for $500 \mathrm{ppm}$ as much as $1000 \mathrm{ml}$ by dissolving $0.5 \mathrm{ml}$ of Moringa extract into 999.5 $\mathrm{ml}$ of distilled water.

\section{Phytochemical Test}

1) Alkaloid Test

The test was carried out by taking $2 \mathrm{ml}$ of Moringa leaf extract samples into a test tube. Then add the extract with five drops of Dragendrof's reagent. If the solution forms an orange precipitate, it is positive that it contains alkaloids [10].

2) Flavonoid Test

The test was carried out by taking $2 \mathrm{ml}$ of Moringa leaf extract samples into a test tube. Then add 0.1 grams of $\mathrm{Mg}$ metal and five drops of concentrated $\mathrm{HCl}$. If the solution is orange to red, it is positive that it contains flavonoids [10].

3) Tannin Test

The test was carried out by taking $2 \mathrm{ml}$ of Moringa leaf extract sample into a test tube, then adding a few drops of $1 \% \mathrm{FeCl} 3$. If the solution forms a blue-green or blue-black color, it is positive that it contains tannins [10].

4) Saponin Test

The test was carried out by taking $2 \mathrm{ml}$ of
Moringa leaf extract samples into a test tube. Then add $3 \mathrm{ml}$ of distilled water. Shake vigorously, then let sit for 30 seconds. After that, observe the foam that is formed. The test results show a positive saponin if the foam height is $1 \mathrm{~cm}$ within 30 seconds [11].

\section{Test Sample Preparation}

The sample used is A36 steel with a chemical composition of $0.20 \% \mathrm{C}, 0.24 \% \mathrm{Si}$, $0.0107 \% \mathrm{Mn}, 0.00025 \% \mathrm{P}$, and $0.00024 \% \mathrm{~S}$. Furthermore, A36 steel is cut with a size of 40 mm x $30 \mathrm{~mm}$. x $4 \mathrm{~mm}$ using a grinder. Next, a hole was given at the top of the sample using a drilling machine as a place to hang the sample. Then the steel samples were sanded using sandpaper grades 80, 500, and 1000 until they were glossy. After that, all samples were washed using distilled water and dried.

\section{Preparation of Corrosion Media}

The solution used for corrosion media in seawater solution. Based on ASTM G31-72, in the laboratory scale immersion test, the total volume of solution for minimal immersion is [12]:

$$
\begin{aligned}
& \text { Solution Volume }=(0.2 \text { to } 0.4) \times \text { Surface } \\
& \text { Area }
\end{aligned}
$$

\section{Weight Loss Test}

The weight loss test was carried out by immersing 25 specimens with inhibitors and five specimens that did not use inhibitors into a seawater immersion solution to compare the results later. Immersion was carried out for seven days. Before and after immersion, the initial and final mass of the specimens were weighed. Then after the soak test is carried out, the corrosion rate is calculated.

\section{Microstructure Analysis}

Microstructural analysis in this study using an optical microscope. Observation of the sample's surface was carried out twice, namely before immersion and after immersion of the sample.

\section{RESULTS AND DISCUSSION \\ Extraction Result of Inhibitor}

The extraction process was carried out using the maceration method to extract samples that were relatively heat resistant. The method is only done by immersing the sample in a solvent for a certain period, without the need for a heating process. In addition to the easy process, it can also avoid damage to the compounds you want to extract. The solvent used is $96 \%$ ethanol. Ethanol solvent could dissolve substances quickly, have high polarity, and be safe to use. 
Moringa leaf extract produced as much as $50 \mathrm{ml}$ of concentrated extract then made one liter of $500 \mathrm{ppm}$ organic inhibitor stock solution by mixing $0.5 \mathrm{ml}$ of Moringa leaf extract into $999.5 \mathrm{ml}$ of distilled water. Furthermore, the inhibitor solution was made in various concentrations, namely 0 ppm, 100 ppm, 200 ppm, $300 \mathrm{ppm}, 400 \mathrm{ppm}$, and $500 \mathrm{ppm}$ as much as $50 \mathrm{ml}$.

\section{Phytochemical Test Results}

Identification of secondary metabolite compounds aims to qualitatively determine the existence of certain groups of secondary metabolites, such as alkaloids, flavonoids, tannins, and saponins.

Phytochemical test results in Table 1 show that Moringa leaves contain all tested secondary metabolites, including alkaloids, flavonoids, tannins, and saponins. The secondary metabolite compounds contained in the Moringa leaf extract can act as corrosion inhibitors that inhibit the metal oxidation process. They meet the characteristics of inhibitors of organic compounds such as the presence of heteroatoms, polar groups, $\pi$ bonds, and lone pairs of electrons, which is a means for the inhibitor to bind to the metal in a coordinated manner [13].

The inhibitory action of some of these natural products has been found due to the presence of organic compounds such as tannins, alkaloids, steroids, amino acids, and flavonoids. Several researchers also reported that the inhibitory effect of some plant solution extracts was caused by the formation of a protective layer on the metal surface due to the adsorption of phytochemical molecules found in plants and deposited on the metal surface as a protective layer [14].

Table 1. Phytochemical Test Results on Moringa Leaf Extract

\begin{tabular}{|c|c|c|c|c|}
\hline Compound & Reactor & Positive Sign & Observation Result & Desc. \\
\hline Alkaloids & Reagen Dragendorf & $\begin{array}{c}\text { Presence of an } \\
\text { orange precipitate }\end{array}$ & & ++ \\
\hline Flavonoids & $\begin{array}{c}\text { Metal Mg + } \\
\text { Concentrated } \mathrm{HCl}\end{array}$ & $\begin{array}{l}\text { Presence of } \\
\text { orange to red } \\
\text { precipitate }\end{array}$ & & ++ \\
\hline Tannins & $\mathrm{FeCl}_{3} 1 \%$ & $\begin{array}{l}\text { The solution } \\
\text { forms a blue- } \\
\text { green or blue- } \\
\text { black color. }\end{array}$ & & +++ \\
\hline Saponins & Aquades & $\begin{array}{l}\text { Stable foam is } \\
\text { formed ( } 1 \mathrm{~cm} \\
\text { high foam for } 30 \\
\text { seconds) }\end{array}$ & & + \\
\hline
\end{tabular}

Description: $(+++)=$ many; $(++)=$ moderate $;(+)=$ less; $(-)=$ none 


\section{Weight Loss Test}

The data used in calculating the corrosion rate is obtained from corrosion testing with the weight loss method. Calculations are carried out using the following equation (ASTM G1- 03) [15]:

Information:

$$
\mathrm{CR}=\frac{K W}{D A T}
$$

$\mathrm{CR}=$ Corrosion rate (mpy)

$\mathrm{W}=$ Weight Loss (grams)

$\mathrm{K}=$ Constant $\left(3.45 \times 10^{6}\right)$

$\mathrm{A}=$ Area $\left(\mathrm{cm}^{2}\right)$

$\mathrm{T}=$ Immersion time (hours)

$\mathrm{D}=$ Density $\left(\right.$ grams $\left./ \mathrm{cm}^{3}\right)$

The addition of inhibitors greatly affects the amount of reduction in sample weight. The immersed samples without inhibitor will have more weight loss than the immersion sample with the addition of an inhibitor. The following is Table 2, which is the data of corrosion rate calculation. In determining the corrosion rate, there were 30 samples divided into six conditions, namely the condition without inhibitor (0 ppm), $100 \mathrm{ppm}$ inhibitor condition, 200 ppm inhibitor condition, 300 ppm inhibitor condition, $400 \mathrm{ppm}$ inhibitor condition, and $500 \mathrm{ppm}$ inhibitor condition. From the six conditions, the average corrosion rate and inhibition efficiency were obtained for each condition of the concentration of Moringa leaf extract.

Table 2. Corrosion Rate Calculation Data

\begin{tabular}{|c|c|c|c|c|c|}
\hline Condition & Sample Name & $\Delta \mathrm{W}($ gram $)$ & $\begin{array}{l}\text { Corrosion Rate } \\
\text { (mpy) }\end{array}$ & $\begin{array}{c}\text { Average } \\
\text { Corrosion Rate } \\
(\mathrm{mpy})\end{array}$ & EI (\%) \\
\hline \multirow{5}{*}{$\begin{array}{l}\text { Without } \\
\text { inhibitor } \\
(0 \mathrm{ppm})\end{array}$} & A01 & 0.09 & 5.78 & \multirow{5}{*}{5.02} & \multirow{5}{*}{0} \\
\hline & $\mathrm{A} 02$ & 0.06 & 3.95 & & \\
\hline & A03 & 0.09 & 6.05 & & \\
\hline & A04 & 0.07 & 4.60 & & \\
\hline & $\mathrm{A} 05$ & 0.07 & 4.70 & & \\
\hline \multirow{5}{*}{$\begin{array}{l}100 \text { ppm of } \\
\text { inhibitor }\end{array}$} & B01 & 0.04 & 2.61 & \multirow{5}{*}{2.26} & \multirow{5}{*}{54.98} \\
\hline & B02 & 0.05 & 3.27 & & \\
\hline & B03 & 0.04 & 2.81 & & \\
\hline & B04 & 0.02 & 1.30 & & \\
\hline & B05 & 0.02 & 1.31 & & \\
\hline \multirow{5}{*}{$\begin{array}{c}200 \text { ppm of } \\
\text { inhibitor }\end{array}$} & $\mathrm{C} 01$ & 0.04 & 2.62 & \multirow{5}{*}{2.03} & \multirow{5}{*}{59.56} \\
\hline & $\mathrm{C} 02$ & 0.04 & 2.74 & & \\
\hline & $\mathrm{C} 03$ & 0.03 & 2.04 & & \\
\hline & $\mathrm{CO} 4$ & 0.03 & 2.07 & & \\
\hline & $\mathrm{C} 05$ & 0.01 & 0.68 & & \\
\hline \multirow{5}{*}{$\begin{array}{l}300 \text { ppm of } \\
\text { inhibitor }\end{array}$} & D01 & 0.02 & 1.34 & \multirow{5}{*}{1.58} & \multirow{5}{*}{68.44} \\
\hline & D02 & 0.04 & 2.62 & & \\
\hline & D03 & 0.04 & 2.65 & & \\
\hline & D04 & 0.01 & 0.65 & & \\
\hline & D05 & 0.01 & 0.66 & & \\
\hline \multirow{5}{*}{$\begin{array}{l}400 \text { ppm of } \\
\text { inhibitor }\end{array}$} & E01 & 0.03 & 1.93 & \multirow{5}{*}{1.45} & \multirow{5}{*}{71.03} \\
\hline & E02 & 0.02 & 1.31 & & \\
\hline & E03 & 0.02 & 1.36 & & \\
\hline & E04 & 0.02 & 1.31 & & \\
\hline & E05 & 0.02 & 1.36 & & \\
\hline \multirow{5}{*}{$\begin{array}{c}500 \text { ppm of } \\
\text { inhibitor }\end{array}$} & F01 & 0.01 & 0.66 & \multirow{5}{*}{1.07} & \multirow{5}{*}{78.71} \\
\hline & F02 & 0.01 & 0.71 & & \\
\hline & F03 & 0.02 & 1.32 & & \\
\hline & F04 & 0.02 & 1.32 & & \\
\hline & F05 & 0.02 & 1.32 & & \\
\hline
\end{tabular}

The addition of an inhibitor is quite influential on the weight loss of steel when immersed for seven days in a corrosive media of seawater. The effect of inhibitor concentration on the corrosion rate is shown in Figure 1. The highest corrosion rate value was obtained for A36 steel without adding an inhibitor, which was 5.02 mpy. Samples with the addition of inhibitors have a corrosion rate value that 
decreases along with the increasing number of inhibitors added to the corrosion media. The 2.26 mpy, $2.03 \mathrm{mpy}, 1.58 \mathrm{mpy}, 1.45 \mathrm{mpy}$, and $1.07 \mathrm{mpy}$ in seawater with an inhibitor concentration of 100 ppm, 200 ppm, 300 ppm, 400 ppm, and 500 ppm, respectively. The greater the value of the inhibitor concentration added, the value of the corrosion rate will also be smaller. Based on the test results, it was found that the inhibitor of Moringa leaf extract was able to work optimally with an inhibitor concentration of $500 \mathrm{ppm}$.

Calculation of the efficiency of Moringa leaf extract inhibitors in inhibiting the corrosion rate can be done using the following equation [16]:

$$
\mathrm{EI}(\%)=\frac{\mathrm{CR} 0-C R 1}{C R 1} \times 100 \%
$$

Information:

$\mathrm{EI}=$ Inhibitor Efficiency $(\%)$

$\mathrm{CR}_{0}=$ Average corrosion rate without inhibitor (mpy)

$\mathrm{CR}_{1}=$ Average corrosion rate with inhibitor (mpy)

From Figure 2, the inhibitor efficiency value of Moringa leaf extract against corrosion of A36 steel increases with increasing the given concentration of inhibitor; the greater the inhibitor concentration added, the greater the inhibition efficiency value produced. In the graph, the highest inhibitor efficiency was found at $500 \mathrm{ppm}$ inhibitor concentration, reaching $78.71 \%$, and the lowest efficiency at $54.98 \%$ with the addition of $100 \mathrm{ppm}$

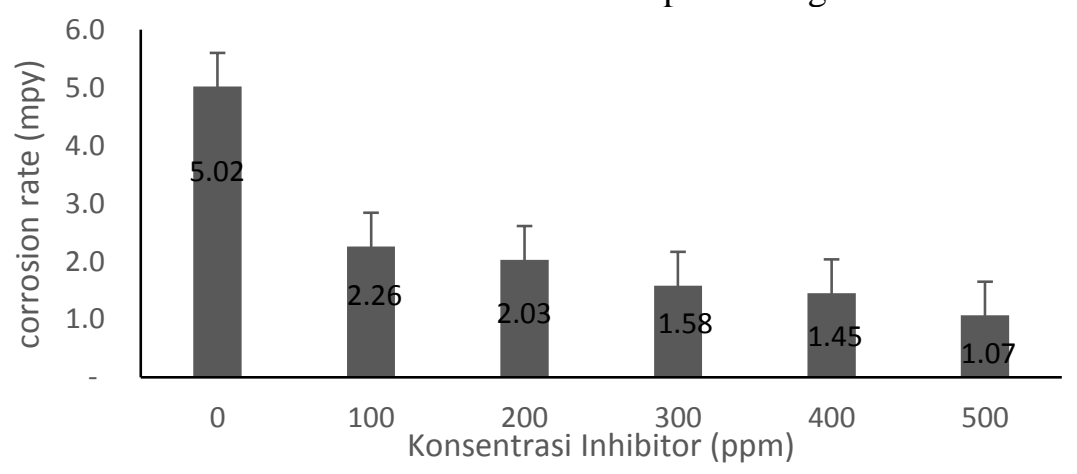

Figure 1. Inhibitor Concentration (ppm) on Corrosion Rate (mpy) of Moringa Leaf Extract

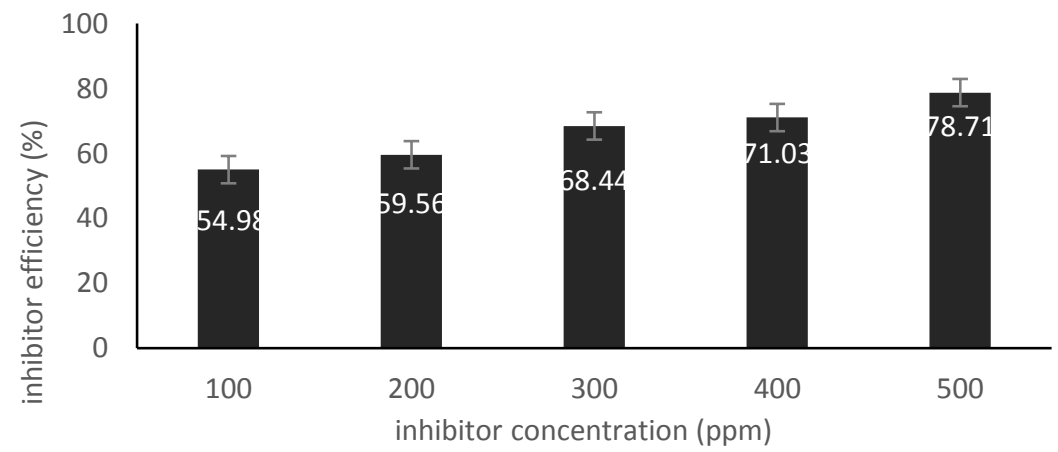

Figure 2. The Effect of Inhibitor Concentration (ppm) on Inhibition Efficiency (\%) of Moringa Leaf Extract 


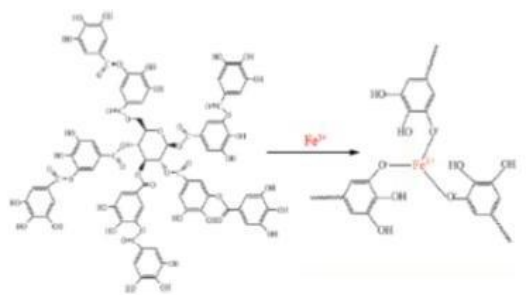

Figure 3. Formation of $\mathrm{Fe}$ tannate Complex Compounds

\section{Results of Visual Observation Sample}

Images were taken on samples before and after being treated and on each sample with variations in the concentration of inhibitor added. This aims to see the comparison of conditions in the sample before and after the immersion process. The following is a picture of the sample before and after immersion in each variation of the concentration of the addition of the inhibitor.

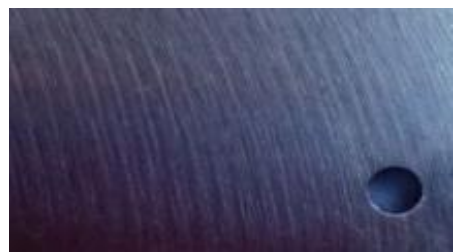

Figure 4. Surface Morphology of Samples Before Immersion

In Figure 4, the surface is still flat, clean, and there are no holes. This means that the steel has not been corroded because there has been no influence from corrosive substances.

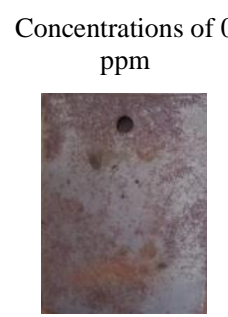

Concentrations of $300 \mathrm{ppm}$

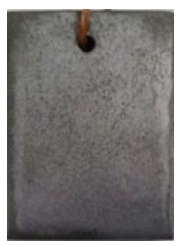

Concentrations of $100 \mathrm{ppm}$

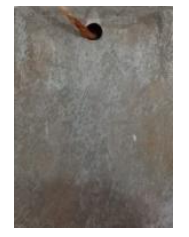

Concentrations of $400 \mathrm{ppm}$

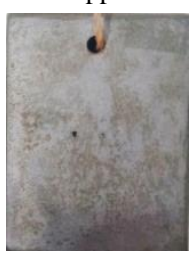

Concentrations of 200 ppm

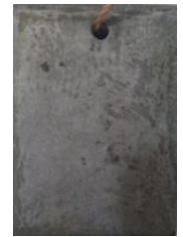

Concentrations of $500 \mathrm{ppm}$

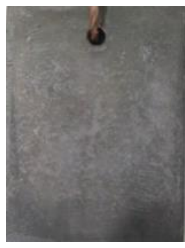

Figure 5. Surface Morphology of Samples After the Immersion

Figure 5 shows the surface morphology of the steel specimen after being immersed for

seven days in a corrosive solution of seawater without the addition of an inhibitor. The steel has been corroded, and there has been damage to the steel surface. Meanwhile, photos of the surface morphology of steel specimens with the addition of inhibitors showed a significant difference. On the surface of the steel, with the addition of inhibitors, a thin dark greenish layer was seen covering the surface of A36 steel and was identified as an oxide layer that could inhibit corrosion. Thus, the function of Moringa leaf extract as a corrosion inhibitor has been seen visually. With the addition of the inhibitor concentration added, the corrosion rate decreases. The greater the concentration of inhibitor added to the corrosive media of seawater, the lower the corrosion rate.

\section{Observation Results of Microstructure Sample}

In this study, observations were done on A36 steel before and after immersion in corrosion media using a microscope with a magnification of 40x so that the observed object could be seen clearly. The results of optical microscope observations of A36 steel are shown below.

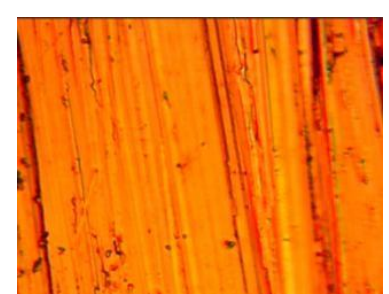

Figure 6. The surface of A36 40x Steel Specimen No Corrosion

Figure 6 is an image of the structure's surface at a magnification of $40 \mathrm{x}$, which is not undergoing a corrosion process. It can be seen in the picture before immersion. There are scratches on the surface of the sample that occurs because of the sanding process.

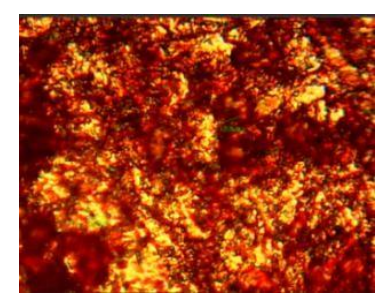

Figure 7. The surface of A36 Steel Specimen 40x Concentration 0 ppm 


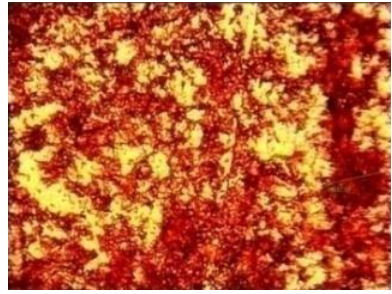

Figure 8. The surface of A36 Steel Specimen 40x Concentration 100 ppm

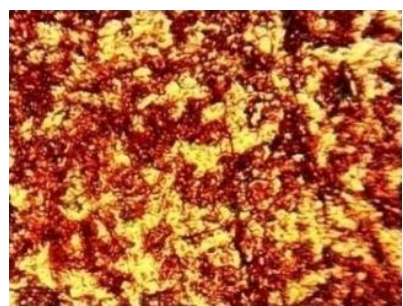

Figure 9. The surface of A36 Steel Specimen

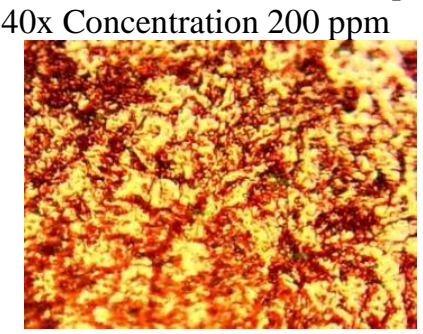

Figure 10. The surface of A36 Steel Specimen

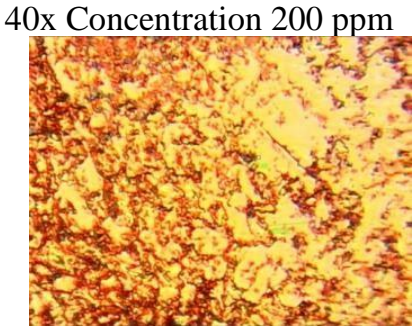

Figure 11. The surface of A36 Steel Specimen 40x Concentration 400 ppm

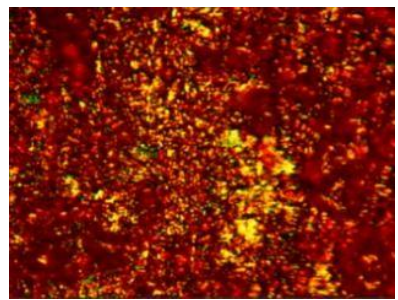

Figure 12. The surface of A36 Steel Specimen 40x Concentration 500 ppm

Microstructural observations on A36 steel show that the greater the concentration of inhibitor of Moringa leaf extract added, the corrosion is seen on the steel surface also decreases. On the sample's surface without inhibitors, more corrosion products are seen and have a rough surface. While the sample with the addition of inhibitor with a concentration of 500 ppm, the surface looks smoother with fewer corrosion products. It is indicated by looking at the optical photo at 40x magnification. The rust formed decreases with the increase in the concentration of the inhibitor used. Inhibitors can form a layer that can block the attack of aggressive ions such as acids and salts. The steel surface becomes protected and protected, which causes the corrosion process to take place more slowly.

The results of the visual observation on the A36 steel surface sample showed that the results were consistent with the research conducted by [19-20], which reported a change in the color of the surface of the sample from several variations in the volume of the inhibitor used. Where the sample without the addition of an inhibitor (control) is clearly visible corrosion, it is characterized by a brownish-red color that forms on the metal surface. It happens because the aggressive $\mathrm{NaCl}$ ions quickly attack the sample without any protection. Meanwhile, along with the addition of inhibitors to the steel sample, the corrosion formed decreases. It is because the inhibitor mixed in the corrosive medium can protect the sample by forming a protective layer on the surface of the steel sample.

Based on the results of observations on the surface of the sample, the type of corrosion that occurs in the sample is pitting corrosion. It can be seen from the corrosion in the form of wells in the form of small holes on the surface of the steel, which is the result of the reaction of iron with chloride ions in seawater solution.

\section{CONCLUSION}

Organic inhibitors from Moringa leaf extract (Moringa oleifera) can reduce the orrosion rate of A36 steel to 1,06772 mpy with an efficiency value of $78.71 \%$ with the addition of an inhibitor concentration of $500 \mathrm{ppm}$ in the seawater solution.

\section{REFERENCES}

[1] Soltani, N., Tavakkoli, N., khayatkashani, M., Jalali, M.R., Mosavizade, A. (2012). Green approach to corrosion inhibition of 304 stainless steel in hydrochloric acid solution by the extract of Salvia officinalis leaves. Corrosion Science. doi: 10.1016/j.corsci.2012.05.003.

[2] Singh, P., Quraishi, M.A., Singh, A., Ebemso, E. (2012). Cetirizine: A New and Effective Corrosion Inhibitor for Mild Steel in $1 \mathrm{M} \mathrm{HCl}$ solution. International Journal of Electrochemical Science, 7 (2012) 7065 7079.

[3] Pradityana, A., Sulistijono, and Shahab, A. (2014). Penggunaan bio inhibitor dalam pipe plant industri migas. ITS, pp. 1-8.

[4] Umoren, S., A. (2016). Biomaterials for 
corrosion protection: evaluation of mustard seed extract as eco-friendly corrosion inhibitor for X60 steel in acid media. Journal of Adhesion Science and Technology, Volume 30, 2016-Issue 17.

[5] Rizkayanti, R., Diah, A,W, M., and Jura, R. (2017). Uji Aktivitas Antioksidan Ekstrak Air Dan Ekstrak Etanol Daun Kelor (Moringa Oleifera LAM ). Jurnal Akademika Kimia., vol. 6, no. May, pp. 125-131.

[6] Amburika, N., A., Sutoyo., S. (2019). Penggunaan Ekstrak Metanol Tumbuhan Paku Perak (Pityrogramma calomelanos) Sebagai Inhibitor Organik dalam Penurunan Laju Korosi Baja ASTM A36. Prosiding Seminar Nasional Kimia, Jurusan Kimia FMIPA Universitas Negeri Surabaya.

[7] Sari, D. M., Handani, S and Yetri, Y. (2013). Pengendalian Laju Korosi Baja St-37 dalam Medium Asam Klorida dan Natrium Klorida Menggunakan Inhibitor Ekstrak Daun Teh (Camelia sinensis). Jurnal Fisika Unand Vol. 2, no. 3, pp. 204-211.

[8] Yufita, E., Fitriana, D., and Zulfalina. (2018). Pengendalian Laju Korosi pada Baja Plat Hitam A36 dalam Medium Korosif Menggunakan Inhibitor Ekstrak Daun Salam. J.Aceh Phys. Soc., Vol. 7, no. 2, pp. 67-71.

[9] Ichsan, D. K. (2008). Pemanfaatan Ekstrak Daun Kelor (Moringa Oleifera) sebagai Green Corrosion Inhibitor pada Material Pipeline API 5L grade B di Lingkungan Air Laut," pp. 1-8,.

[10] Ergina, E., Nuryanti, S., and Pursitasari, I, D, . (2014). Uji Kualitatif Senyawa Metabolit Sekunder Pada Daun Palado (Agave Angustifolia) Yang Diekstraksi Dengan Pelarut Air Dan Etanol. Jurnal Akademika Kimia, vol. 3, no. August, pp. 165-172,.

[11] Yuda, P. E. S. K., Cahyaningsih, E. and Winariyanthi, N. L. Y. (2017). Skrining Fitokimia Dan Analisis Kromatografi Lapis Tipis Ekstrak Tanaman Patikan Kebo (Euphorbia hirta L.). Jurnal Ilmiah Medicamento Vol. 3, no. 2, pp. 61-70.

[12] Anonim. (2004). Standard Practice for Laboratory Immersion Corrosion Testing of Metals. ASTM International, 100 Barr Harbor Drive, PO Box C700, West Conshohocken, PA 19428-2959, United States.

[13] De Souza, F. S. and Spinelli, A. (2008). Caffeic acid as a green corrosion inhibitor for mild steel. Corrosion. Science, vol. 51, no. 3, pp. 642-649, 2009, doi: 10.1016/j.corsci..12.013.
[14] Odusote., J. (2013). Corrosion Inhibition Of Mild Steel in Acidic Medium By Jathropha Curcas Leaves Extract. Journal of Electrochemical Science and Technology. doi: 10.5229/JECST.2013.4.2.81

[15] Anonim. (2017). Standard Practice for Preparing, Cleaning, and Evaluating Corrosion Test Specimens G1-03. ASTM International, 100 Barr Harbor Drive, PO Box C700, West Conshohocken, PA 19428-2959, United States.

[16] ASTM Internasional. (2005). Corrosion Test and Standar: Application and Interpretation. Second Edition. ASTM International. Page 23.

[17] Singh, A., Ebenso, E.E., \& Quraishi, M.A. (2012). Corrosion Inhibition of Carbon Steel in HCL Solution by Some Plat Extracts. International Journal of Corrosion. Volume 2012, Article ID 897430, 20 pages doi:10.1155/2012/897430

[18] Xu, W., Han, E. and Wang, Z. (2019). Effect of tannic acid on corrosion behavior of carbon steel in $\mathrm{NaCl}$ solution. Journal of Materials Science \& Technology. vol. 35, no. 1, pp. 6475, doi: 10.1016/j.jmst.2018.09.001

[19] Yufita, E., Fitriana, D., Zulfalina. (2018). Pengendalian Laju Korosi Pada Baja Plat Hitam A36 Dalam Medium Korosif Menggunakan Inhibitor Ekstrak Daun Salam. J.Aceh Phy.Soc, Vol., No.2 pp. 67-71.

[20] Baihaqi, R.A., Pratikno, H., Hadiwidodo, Y, S. (2019). Analisis Sour Corrosion pada Baja ASTM A36 Akibat Pengaruh Asaam Sulfat dengan Variasi Temperatur dan Waktu Perendaman di Lingkungan Laut. Jurnal Teknik ITS Vol.8, No.2, ISSN: 2337-3539 (2301-9271 Print). 